\title{
Article \\ Vegetation Profile for Forest Rehabilitation in Arjuna Mount, East Java, Indonesia
}

\author{
Matheus Nugroho ${ }^{1}$, Soemarno ${ }^{2}$, Harsuko Riniwati ${ }^{3}$, Aminudin Afandhi $^{4}$ \\ ${ }^{1}$ Student of Environmental Science Doctoral Program of Brawijaya University, \\ Postgraduate Program in Malang, East Java, Indonesia; mtnugroho@ gmail.com \\ ${ }^{2}$ Faculty of Agriculture Brawijaya University in Malang, East Java, Indonesia; \\ smno@ub.ac.id \\ ${ }^{3}$ Faculty of Fisheries and Marine Science Brawijaya University in Malang, East Java; \\ Indonesia; riniwatisepk@gmail.com \\ ${ }^{4}$ Faculty of Agriculture Brawijaya University in Malang, East Java, Indonesia; \\ a.afandhi@gmail.com \\ Correspondence: mtnugroho@gmail.com ; Tel.: +62-81-3338-67954
}

\begin{abstract}
. the research objectives was to determine the plants vegetation profile in forest revegetation and Mount Arjuna springs. The method used was descriptive method. While based on the techniques and tools used to research, the author uses the survey method to obtain facts that occur in the research area, namely in the area around the springs of Arjuna mount, Pasuruan, East Java, Indonesia. Data obtained in the field are then processed and analyzed using GIS, ArcView 3.3 and Google Earth programs. The results of the study explain the profile of plant vegetation, namely plant stratification, bird wealth, taxonomic wealth and plant density have a significant effect on forest revegetation and springs in Arjuna mount. The forest vegetation profile has a positive and significant effect on the preservation of springs. The better the profile of forest vegetation, the preservation of springs will be better, and vice versa.
\end{abstract}

Keywords: plant vegetation profile, forest rehabilitation, vegetation stratification, bird wealth, taxonomic wealth, plant density, springs in Arjuna mount

\section{Introduction}

Forest plants vegetation could increase the ability of the soil to store water, because each tree had a different root system and produces different humus. The difference in topsoil influences the porosity of the soil under the tree, while differences in root systems affect the process of absorbing rainwater (infiltration), as well as in suctioning groundwater with nutrients by the roots. Forest plants vegetation had several benefits, namely: (1) producing litter for decomposition (humification and mineralization), which includes nutrients from the soil raised to the surface into biomass, and biomass formed decomposed so humus and minerals (nutrients) are formed in ground level; (2) nitrogen fixation, which includes: plant roots could symbiosis with nitrogen bacteria, nitrogen bacteria are able to fix $\mathrm{N}$ from the atmosphere, free $\mathrm{N}$ will accumulate in biomass, biomass will decompose, then humus and minerals (nutrients) were formed on the ground; (3) protect soil erosion [10].

Forest revegetation was the restoration of productivity, but not all native species of plants and animals exist. For ecological and economic interests the new forest could consist 
of non-native species. Plant cover or vegetation has an important role, that was, as a function of the hydrological system, especially the effect of sponges was that it could hold rainwater and regulate its drainage, thereby reducing erosion, flooding and maintaining water flow in the dry season. The hydrological function of the forest will be lost, when vegetation in the higher watersheds was damaged [4].

The general description of Indonesia's forest ecosystems had been damaged since 1950, and the forest continues to increase in damage after the issuance of the foreign capital companies and domestic capital company Law in the 1970s, where the era of forest exploitation began as a source of national development foreign exchange. Damage to forest resources was increasingly out of control when illegal logging, over cutting, encroachment of forest land for agriculture and forest fires occur. Damage to forest resources was increasingly exacerbated when entering the current era of reform and regional autonomy [7].

The results of USAID's monitoring over the past 20 years indicate that there has been a rate of forest destruction in Arjuna mount, some sub-watershed areas have decreased spring discharge, this was allegedly related to forest destruction in the recharge area continues to increase. The number of dry or dead springs was 30 springs, of a total of 41 springs. The main cause of dry springs was damage to protected forests and production in Arjuna mount. Thousands of hectares of Arjuna mount forest were critical, due to fire and illegal logging. The forest area of Arjuna mount in the Pasuruan, East Java, Indonesia area reaches 12,000 hectares. About 1,500 hectares of them were damaged by fires in 2012. Of the 1,500 hectares burned, only 300 hectares have been rehabilitated. According to the study from the Clinton Foundation, USA in 2011-2012, the rate of forest destruction on Mount Arjuna reached $0.24 \%$, equivalent to 68 ha/year. If this condition continues, it will threaten the supply of clean water for almost 2 million people in Pasuruan, East Java, Indonesia, 4.7 thousand hectares of irrigated rice fields and around 500 industries in Pasuruan [13].

Based on some of the facts and problems mentioned above, so that was needed a study of plant vegetation profile in forest revegetation and springs preservation of Arjuna mount.

\section{Materials and Methods}

Data material was taken from the growth of plant species that exist in each area around the spring by recording and photographing parts that characterize the tree species. The next step was to measure water discharge in the dry and rainy seasons, water quality data. The results of plant species growth data will then be analyzed for plant density, relative density, frequency, relative frequency, importance value, and diversity index [3].

This research was an associative problem, which was a research question that connects two or more variables. The relationship variable in research was a causal relationship, that was a causal relationship. There were independent or exogenous variables, and dependent or endogenous variables. Exogenous variables are selected according to consideration based on empirical conditions, forest revegetation activities and community empowerment around the year forest, the ability of researchers, the availability of supporting theories, and the characteristics of the study area [11].

Exogenous variables in this research plan were:

a) Community empowerment (PM), including: human resources (PM1); economics

(PM2); social (PM3); local institutions (PM4); facilities and infrastructure (PM5)

b) Geography and land (GT), including: land slope (GT1); effective soil depth (GT2)

There were 3 endogenous variables in this study, namely:

a) $\mathrm{RH}$, was a symbol of the Arjuna mount forest revegetation variable in the area of the Lajer, Dawuan, Sumberkuning and Watupereng springs, Prigen, Pasuruan, East Java, 
Indonesia, with indicators including: plant species (RH1); nurseries (RH2); fertilization (RH3); planting (RH4); care (RH5). Forest revegetation was determined by measuring the fulfillment of community empowerment; geography and land.

b) PVH, was a symbol of Arjuna mount vegetation and fauna profile variable, with indicators: vegetation stratification (PVH1); bird wealth (PVH2); taxonomy wealth (PVH3); plant density (PVH4). The profile of vegetation and fauna of Arjuna mount was determined by measuring the fulfillment of forest revegetation, geography and soil conditions and empowerment of communities around the forest.

c) PSA, was a symbol for variable conservation of spring water, with indicators: water discharge in the rainy season (PSA1); water discharge in the dry season (PSA2); erosion (PSA3); economic value of water (PSA4). Conservation of springs is determined by measuring the fulfillment of forest vegetation and fauna profiles, revegetation of forests, geography and soil as well as the empowerment of communities around the forest.

The method used was descriptive method. While based on the techniques and tools used to research, the author uses the survey method to obtain facts that occur in the research area, namely in the area around the springs of Lajer, Dawuan, Watupereng and Sumberkuning in Arjuna mount, Pasuruan, East Java, Indonesia. Data obtained in the field were then processed and analyzed using GIS, ArcView 3.3 and Google Earth programs. The study population covering the community around the forest and springs, who lived in three villages, namely Leduk, Jatiarjo and Dayurejo Village, Pasuruan, East JavaIndonesia. Data obtained from respondents with questionnaires and analyzed using SEM (structural equation modeling), to find out a general description of respondents' responses about community participation in the preservation of Arjuna mount forest.

\section{Results}

\subsection{Vegetation Stratification}

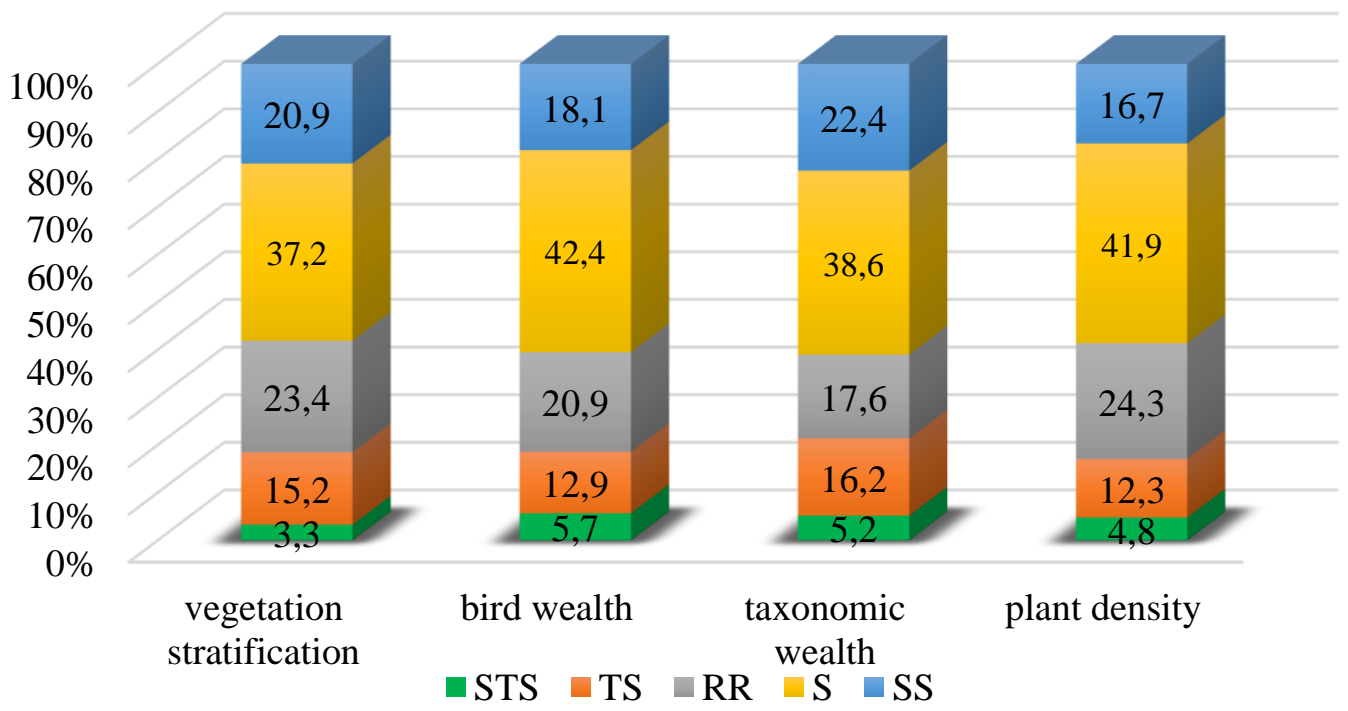

Figure 1. Respondents' perceptions of plant vegetation profile

Note:

STS : explain the perceptions of respondents strongly disagree about community empowerment 
TS : explain the perceptions of respondents disagree about community empowerment

RR : explain the perceptions of respondents hesitant about community empowerment

S : explain the perceptions of respondents agreeing about community empowerment

SS : explain the perceptions of respondents strongly agree about community empowerment programs

The profile of the vegetation stratification in the Arjuna mount forest includes: (1) the height of trees planted around the spring after 3 years reaching a range of 20-25 meters; (2) canopy of canopy trees interlocked, so that forest trees become green and shady; (3) the height of trees planted around the spring area of Lajer, Dawuan, Watupereng and Sumberkuning was also in the range of 4-20 meters; (4) there were many shrubs and shrubs in the lower part of the tree which were in the range of 1-4 meters; (5) most of the soil around the source area of the spring is covered with cover crops such as grass and other thickets.

The perception of 210 respondents to the Arjuna mount forest stratification profile towards the springs preservation of Lajer, Dawuan, Sumberkuning and Watupereng, in Figure 1. explains that $20.9 \%$ of respondents stated strongly agree, $37.2 \%$ of respondents agreed, $23.4 \%$ of respondents expressed doubt, $15.2 \%$ of respondents said they did not agree and $3.3 \%$ of respondents stated strongly disagree. Based on these data, the vegetation profile of the Arjuna mount forest stratification influences the springs preservation of in Lajer, Dawuan, Sumberkuning and Watupereng, because almost $58.1 \%$ of respondents agreed and strongly agreed. Figure 1. explains the responses of respondents about the vegetation stratification profile of the Arjuna mount forest.

\subsection{Bird wealth}

The profile of the Arjuna mount forest birds wealth includes: (1) there were regulations for the protection of animal species in the forest area of Arjuna mount; (2) several species of birds, such as finches, greens cucak, parrots, trocok, crabs can still be found in the forest area of Arjuna mount; (3) various birds such as finches, green cucak, parrots, trocok, kepodang could develop on their own in the forest area of Arjuna mount; (4) based on the species protection law that various species of birds such as finches, green cucak, parrots, trocok, ferns are protected from poaching activities; (5) there was the application of social sanctions for community members who hunt birds in the forest.

Perception of 210 respondents to the bird wealth profile in the Arjuna mountain forest area, in Figure 1 . shows that $18.1 \%$ of respondents stated strongly agree, $42.4 \%$ of respondents agreed, $20.9 \%$ of respondents expressed doubt, $12.9 \%$ of respondents expressed disagreement and $5.7 \%$ of respondents stated strongly disagree. Based on these data, the bird wealth profile of the Arjuna mount forest area illustrates the preservation of the springs of the springs of Lajer, Dawuan, Sumberkuning and Watupereng, because almost $60.5 \%$ of the respondents agreed and strongly agreed. Figure 1. explains the respondent's response to the profile of Arjuna's mount forest bird wealth.

\subsection{Taxonomy wealth}

The taxonomic wealth profile of the Arjuna mount forest includes: (1) tree planting in the spring area; (2) planting various types of trees, endemic plants, springs and fruit plants; (3) plant maintenance by forest farmers; (4) increasing forest biodiversity; (5) caring for forest biodiversity. 
Perception of 210 respondents to the forest taxonomy profile of Arjuna mount, in Figure 1 . shows that $22.4 \%$ of respondents agreed strongly agree, $38.6 \%$ of respondents agreed, $17.6 \%$ of respondents expressed doubt, $16.2 \%$ of respondents expressed disagreement and $5.2 \%$ of respondents stated strongly disagree. Based on these data stated the taxonomic wealth profile of the Arjuna mount forest illustrates the springs vegetation preservation in Lajer, Dawuan, Sumberkuning and Watupereng, this was evidenced by the perception of respondents of $61 \%$ agreeing and strongly agree. Figure 1. explains the respondent's response to the taxonomic profile of the Arjuna mount forest.

\subsection{Plant density}

The density profile of the Arjuna mount forest plant includes: (1) the distance of the dense and lush plants; (2) the density of plants increases, between trees more and more branches and leaves; (3) plant density was maintained and not damaged; (4) the number of tree stands was very large; (4) plant density can prevent erosion or landslides in the rainy season.

The perception of 210 respondents towards the Arjuna mount forest plant density profile, in Figure 1. shows that $16.7 \%$ of respondents strongly agreed, $41.9 \%$ of respondents agreed, $24.3 \%$ of respondents expressed doubt, $12.3 \%$ of respondents stated disagree and $4.8 \%$ of respondents stated strongly disagree. Based on these data the density profile of the Arjuna mount forest plant illustrates the preservation of the vegetation of the spring springs of Lajer, Dawuan, Sumberkuning and Watupereng, because almost 58.6\% of respondents said they agreed and strongly agreed. Figure 1. explains the respondent's response to the Arjuna mount forest density profile.

\subsection{Structural model the effect of the plants vegetation profile in forest revegetation and Mount Arjuna springs}

Structural model testing was used to test the research hypothesis. Stages in structural model testing include structural model formation stage, structural model feasibility test and test the significance of the influence of endogenous variables on endogenous variables.

\subsubsection{Structural model specifications}

By referring to the hypotheses and framework of the model constructed in this study, the specification of the structural model of SEM (structural equation modeling) analysis built in this study was figure 2 .

\subsubsection{Structural model suitability test}

The suitability test of the structural model in SEM (structural equation modeling) analysis was done by looking at some criteria of goodness of fit model such as chi square value, probability, df (degrees of freedom), GFI (goodness of fit indices), AGFI (adjust goodness of fit), TLI (trucker lewis index), CFI (comparative fit index), RMSEA (root mean square error of approximation) and SRMR (standardized root mean squared). In this test, the structural model was stated to have fulfilled the goodness of fit model criteria if the model meets one of the assumptions contained in the table above. [11] states that if there were one or two goodness of fit criteria that have been fulfilled, then it can be said that the model built was good. Based on the estimation results of the structural measurement shows that the structural model has not been so good in meeting the criteria of goodness of fit model, the probability of the model was still below 0.05 , which means that with the model, 210 samples have not had the same covariance matrix with the actual population covariance matrix, so it was necessary to modify the model. Modification 
indices to increase the goodness of fit model, then add paths between error e1 and e2, e4 and e5, e7 and e9, e9 and e10, e17 and e20, and in the path between e14 and e15. The results of the goodness of fit model test after the three lines were added presented in figure 2. shows that after the modification of the model, the model has a probability above 0.05 , thus, the model has been used to test the hypothesis in this study.

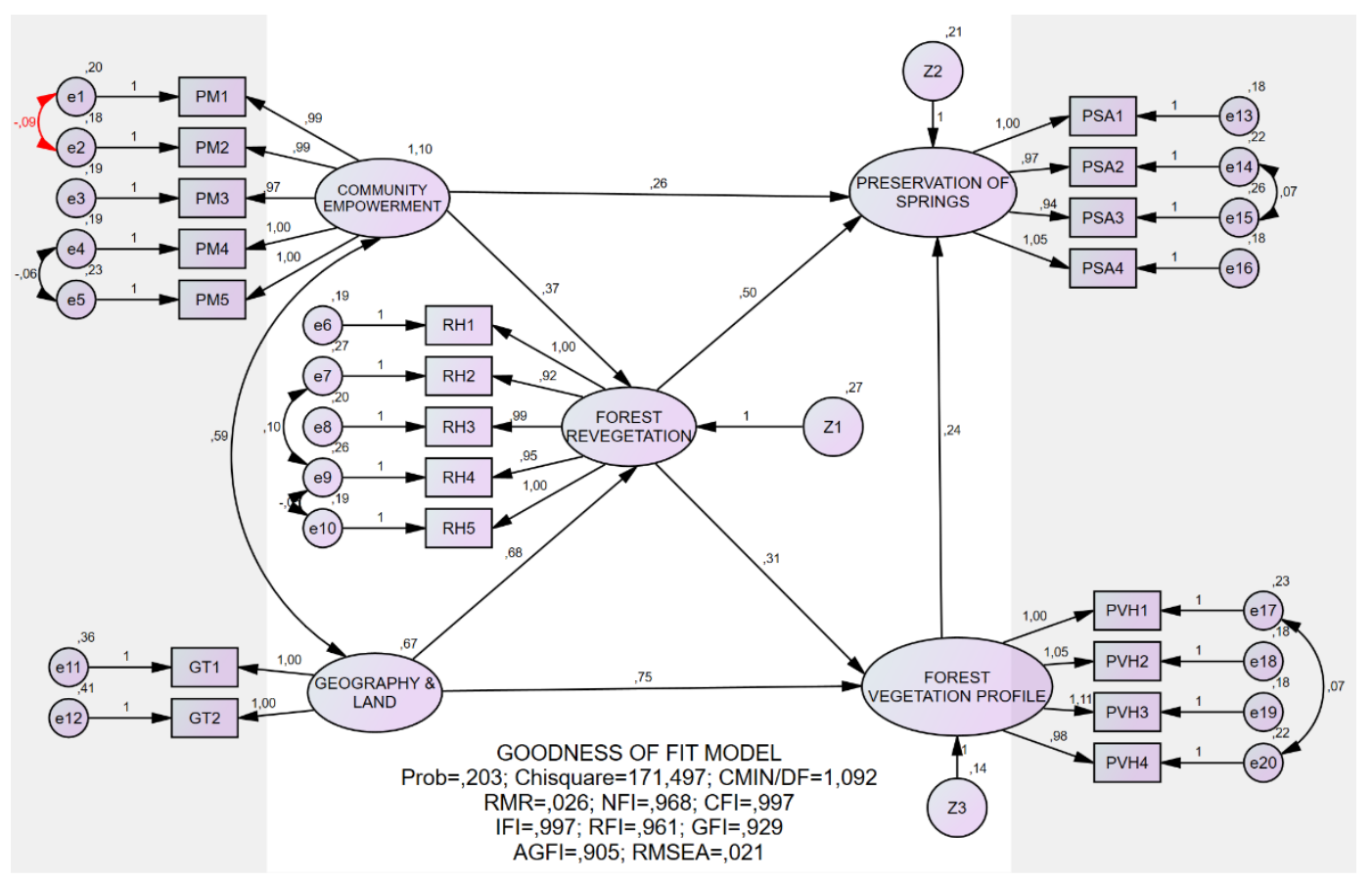

Figure 2. Results of estimation of structural model modifications

\subsubsection{Significance test}

The significance test aims to examine whether there was a significant influence of exogenous variables on endogenous variables. The hypothesis built in this test was as: H0: There was no significant effect of exogenous variables on endogenous variables $\mathrm{H} 1$ : There was a significant effect of exogenous variables on endogenous variables, with a significant level of $0.05, \mathrm{H} 0$ will be rejected if significant values $\mathrm{P}$ (probability) $<0.05$ and $\mathrm{CR}$ (critical ratio) $>1.96$, while if the significant value $\mathrm{P}$ (probability) $>0.05$ and $\mathrm{CR}$ (critical ratio) $<1.96$ then $\mathrm{H} 0$ was not rejected.

Table 1. Test results of signifikansi regression weights

\begin{tabular}{|c|c|c|c|c|c|c|c|}
\hline & & & Estimate & S.E. & C.R. & $\mathrm{P}$ & Label \\
\hline $\begin{array}{l}\text { forest } \\
\text { revegetation }\end{array}$ & $<--$ & $\begin{array}{l}\text { community } \\
\text { empowerment }\end{array}$ & 0.374 & 0.075 & 5.005 & $* * *$ & par_15 \\
\hline $\begin{array}{l}\text { forest } \\
\text { revegetation }\end{array}$ & $<---$ & $\begin{array}{l}\text { geography } \\
\text { and land }\end{array}$ & 0.679 & 0.108 & 6.273 & $* * *$ & par_16 \\
\hline $\begin{array}{l}\text { forest vegetation } \\
\text { profile }\end{array}$ & $<--$ & $\begin{array}{l}\text { forest } \\
\text { revegetation }\end{array}$ & 0.312 & 0.101 & 3.084 & 0.002 & par_18 \\
\hline $\begin{array}{l}\text { forest vegetation } \\
\text { profile }\end{array}$ & $<--$ & $\begin{array}{l}\text { geography } \\
\text { and land }\end{array}$ & 0.750 & 0.141 & 5.299 & $* * *$ & par_20 \\
\hline
\end{tabular}




\begin{tabular}{|c|c|c|c|c|c|c|c|}
\hline & & & Estimate & S.E. & C.R. & $\mathrm{P}$ & Label \\
\hline $\begin{array}{l}\text { preservation of } \\
\text { spring water }\end{array}$ & $<---$ & $\begin{array}{l}\text { forest } \\
\text { revegetation }\end{array}$ & 0.503 & 0.087 & 5.760 & $* * *$ & par_17 \\
\hline $\begin{array}{l}\text { preservation of } \\
\text { spring water }\end{array}$ & $<--$ & $\begin{array}{l}\text { community } \\
\text { empowerment }\end{array}$ & 0.256 & 0.059 & 4.344 & **** & par_19 \\
\hline $\begin{array}{l}\text { preservation of } \\
\text { spring water }\end{array}$ & $<---$ & $\begin{array}{l}\text { forest } \\
\text { vegetation } \\
\text { profile }\end{array}$ & 0.241 & 0.083 & 2.914 & 0.004 & par_21 \\
\hline
\end{tabular}

Based on the analysis of regression weights SEM (structural equation model), in Figure 2 ., it shows that the profile variable of plant vegetation had a significant effect on the preservation of springs on Arjuna mount. The better the plant vegetation profile, the better forest preservation and source of water will be.

The estimated value of SEM regression (structural equation model), in Figure 2., for each indicator of plant vegetation profile shows vegetation stratification $=1.00$, bird wealth $=1.05$, taxonomic wealth $=1.11$ and plant density $=0.98$. This condition indicates that according to respondents the vegetation profile of the plant had a significant influence on the preservation of the forests and springs of Arjuna mount.

\section{Discussion}

\subsection{Vegetation Stratification}

Some of the obstacles faced in the stratification of tree vegetation in Arjuna mount forest were that the growth of tall trees was not the same, so stratification or coating of tree canopy had not been formed. Stratification formed from canopy arrangements of trees can become forest vegetation for water absorption. In forest ecosystems, stratification was formed from the canopy arrangement of several plants, in the form of a vertical direction, this condition occurs because of the composition of dominant, codominant, intermediate, depressed, and lower tree class plants [3].

Some of the successes of tree stratification improvements that have been done carried out for the Arjuna mountain forest revegetation were carrying out planting with the same type and height of trees, and replacing dead plants with new plants whose height was the same as plants that have grown long. In 2014 revegetation in the area of Lajer's spring area of 10 hectares, 700 trees had been added to replace dead plants. The percentage of live plants after 3 years of monitoring was 94\%, meaning that from 3000 trees planted in 2014, in the third year of monitoring, there were 2016 plants that lived as many as 2873 trees.

In 2015 revegetation in the Dawuan springs area of 5 hectares, 205 trees were added as a replacement for dead plants. The percentage of live plants after 3 years of monitoring was $92 \%$, meaning that out of 1500 trees planted in 2015, in the third year of monitoring, there were 1380 trees that live.

In 2016 revegetation in the Sumberkuning springs area of 25 hectares, there were no additional plants for 3 years of monitoring and maintenance. The percentage of live plants after 3 years of monitoring was $86 \%$, meaning that of the 5000 trees planted in 2016, in the third year of monitoring, 2018 plants lived as many as 4485 trees.

In 2017 and 2018 revegetation in the 53 hectare Watupereng spring area, there were no additional plants for 3 years of monitoring and maintenance. The percentage of live plants after 3 years of monitoring was $99 \%$, meaning that from 8000 trees planted at the beginning of the planting year, in the first year of monitoring, that was December 2018, 7958 trees live.

Based on the survey results and socialization in the group discussion, the objectives to be carried out with the maintenance and improvement of plant stratification for revegetation 
of the Arjuna mountain forest for the second period of 2019-2020 were tree planting according to the height of the plant location, requirements for plant species, minimum plant height, plant species endemic and spring water plant species.

\subsection{Bird wealth}

Some of the obstacles faced in the bird wealth preservation of the Arjuna mount forest area were the occurrence of poaching, and forest fires in every dry season in the area around the source of water, this causes the number of bird species such as finches, green cucak, parrots, trocok and many pigeons reduced and difficult to obtain. Healthy forest was a conservation area to preserve various species of birds. Forests were a source of various types of natural foods for all types of animals including the types of fruit-eating birds. Revegetation of fruit trees also supports the provision of food sources for various types of fruit-eating birds, therefore the occurrence of forest fires will have an impact on the preservation of biodiversity [2].

Some of the successes in improving the sustainability of bird wealth in the Arjuna mount forest area were (1) planting fruit trees, as a food source for various fruit-eating birds; (2) carry out plant maintenance to maintain the preservation of biodiversity. There were mutually beneficial relationships and interactions between birds and plants. Diaspora of plants will be spread far from its parent plants, because of the help of birds in its spread. Plant seeds will also germinate faster because the skin and flesh of the fruit have been destroyed when passing through the digestion of birds. Birds also benefit from these interactions especially for fruit-eating or nectar birds that use plant parts as food sources [6]. Based on the results of the survey and outreach in group discussions, the objectives to be implemented to improve the sustainability of bird wealth in the Arjuna mountain area in the second period of 2019-2020 were (1) planting fruit trees, as a food source for various fruit-eating birds. The types of fruit trees planted include avocados (Persea americana) with 1500 trees; oranges (Citrus sp) number of 1000 trees; coffee (Coffea sp) with 1000 trees; soursop (Annona muricata) with 1500 trees; durian (Durio sp) with 1000 trees and guava (Psidium guajava) with 1000 trees. (2) releasing various types of fruit-eating birds in the revegetation area of Arjuna mount forest.

\subsection{Taxonomy wealth}

Table 1. Tree planting of the Arjuna mount forest for the 2014-2018 period

\begin{tabular}{|c|c|c|c|c|}
\hline NO & Year & Revegetation location & $\begin{array}{c}\text { Nmber of } \\
\text { trees }\end{array}$ & $\begin{array}{c}\text { Area } \\
\text { (hectar) }\end{array}$ \\
\hline 1 & 2014 & Lajer - Arjuna mount & 3000 & 10 \\
\hline 2 & 2015 & Dawuan - Arjuna mount & 1500 & 5 \\
\hline 3 & 2016 & Sumber Kuning - Arjuna mount & 5000 & 25 \\
\hline 4 & 2017 & Watu Pereng - Arjuna mount & 6000 & 34 \\
\hline 5 & 2018 & Watu Pereng - Arjuna mount & 4000 & 19 \\
\hline Total & & 19500 & 93 \\
\hline
\end{tabular}

Source: [8]

Some of the obstacles faced in the preservation of the taxonomic wealth of the Arjuna mount forest were (1) the change in the function of protected forests into production forests and tourist destinations, low plant biodiversity production forests; (2) forest fires in the dry season, plant pests and diseases, and damage to plants by animals and humans reducing biodiversity; (3) the types of plants planted were not in accordance with the ecosystem of forest heights. The higher the level of taxon wealth or forest biodiversity, the higher the level of health and sustainability of the forest, because the higher the biodiversity the more 
complex the ecological processes that occur so that the level of stability was high [5]. [1], explained that the analysis of species biodiversity measurement requires two indicator data, namely (1) data on the number of species richness and (2) density or abundance.

Some of the successes in improving the sustainability of the wealth of the taxon of the Arjuna mount forest were the planting of various species of trees, from endemic species of plants, springs and fruits. The total number of plants was 19500 trees, with an area of revegetation of 93 hectares, in the area around the springs of Lajer, Dawuan, Sumberkuning and Watupereng, which were carried out for 5 years as explained in Table 1.

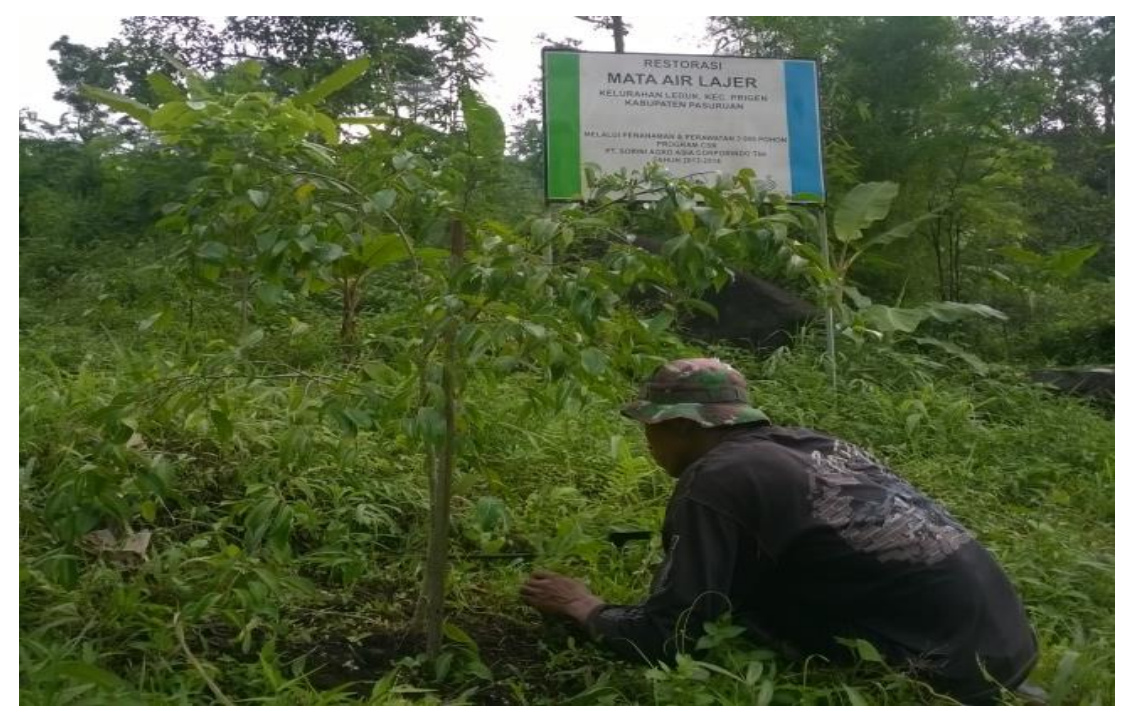

Figure 3. Tree plantng in Lajer springs, Leduk-Prigen Pasuruan

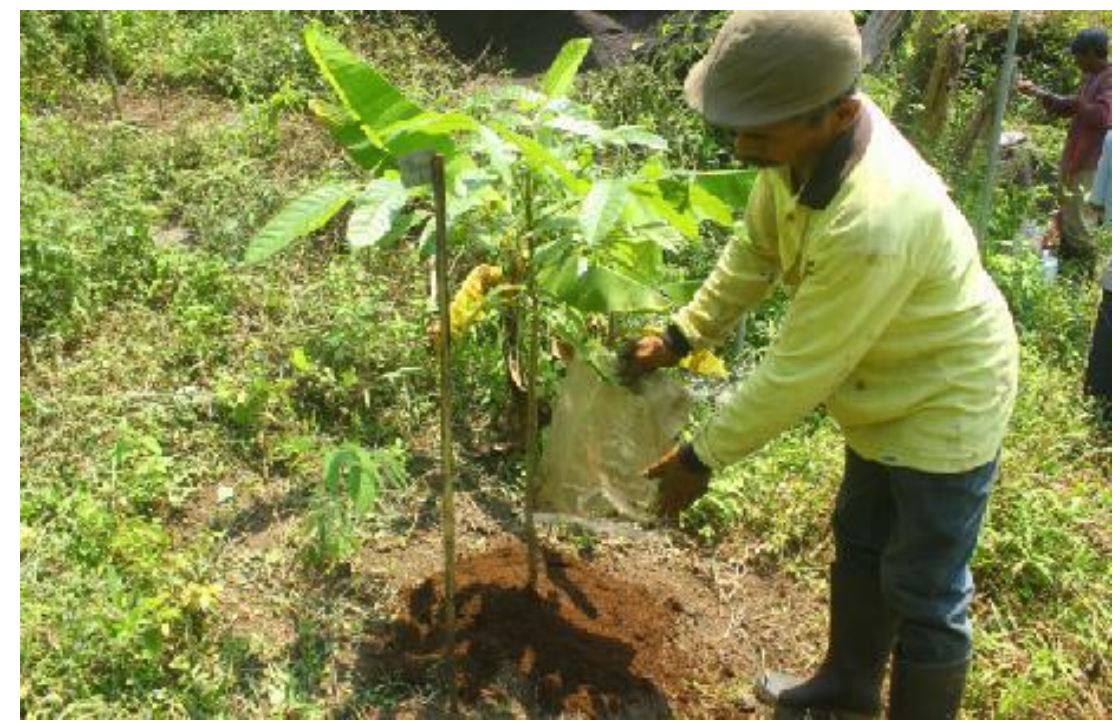

Figure 4. Tree planting in Dawuan springs, Leduk -Prigen Pasuruan

Planting 3000 trees in the Lajer springs area, with plants including 1000 bamboo (Dendrocalamus asper), 600 candlenuts (Aleurites moluccana), 400 kluwek (Pangium edule), 300 kluweh (Artocarpus communis), 100 banyans (Ficus benyamina), 500 durian (Durio sp) and 100 elo (Ficus glomerata). 
Planting 1500 trees in the Dawuan spring area, with types of plants including petung bamboo petung (Dendroca-lamus asper) 300 trees, candlenut (Aleurities mollucana) 500 trees, banyan (Ficus benyamina) 50 trees, bendo (Artocarpus elasticus) 450 and ivory plant 200 trees.

Planting 5000 trees in the Sumber Kuning spring area, with plants including mountain cypress (Casuarina junghuniana) 2000 trees, swirling 300 trees, petung bamboo (Dendrocalamus asper) 500 trees, cap (Mallocus moluccana) 200 trees, mlandingan (Leucaena glauca) ) 500 trees, kaliandra (Calliandra calothyrsus) 1000 trees and gmelina (Gmelina arbora) 500 trees.

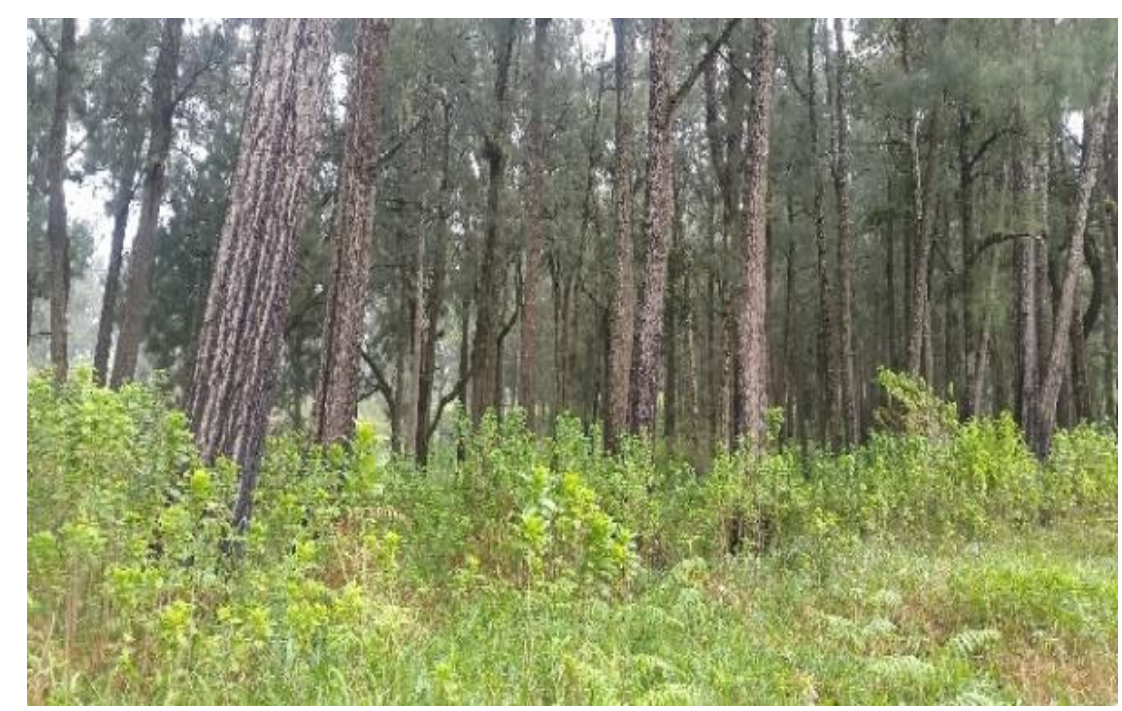

Figure 5. Tree planting in Sumber Kuning springs, Prigen, Pasuruan

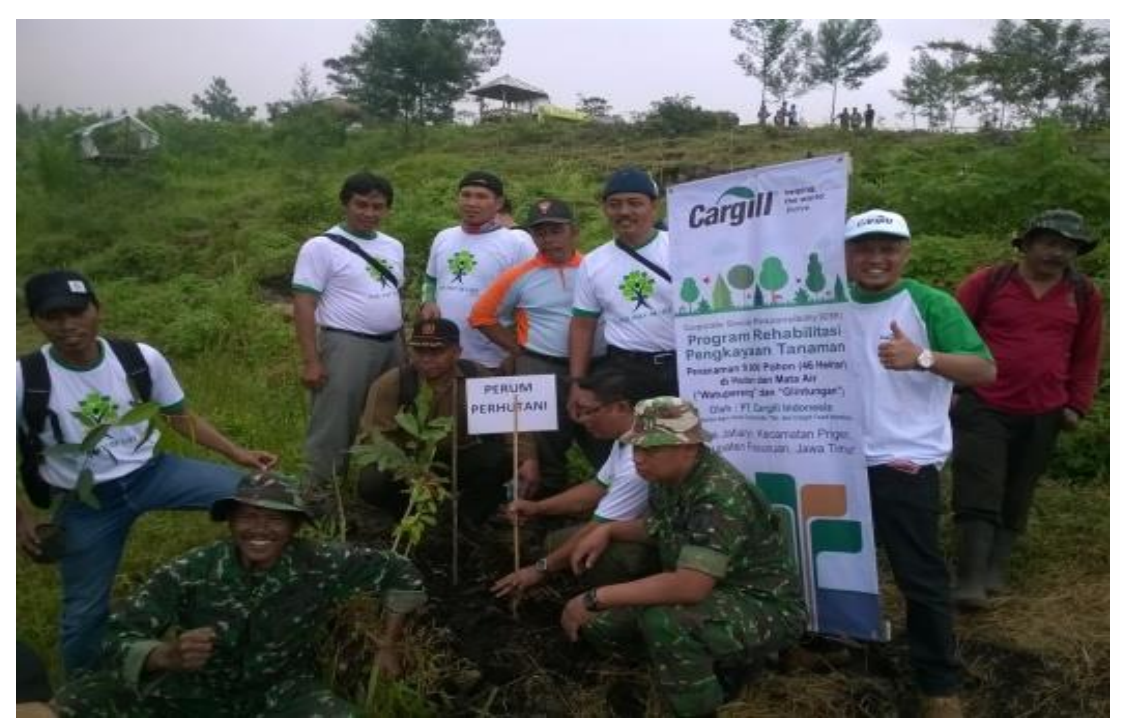

Figure 6. Tree planting in Watu Pereng springs Jatiarjo, Prigen, Pasuruan

Planting 8000 trees in the Watu Pereng spring area, with plant species including petung bamboo (Dendrocalamus asper) 1300 trees, banyan (Ficus sp) 500 trees, kluweh (Artocarpus communis) 180 trees, candlenuts (Aleurities mollucana) 450 trees, matoa 
(Pometia pinnata) 820 trees, cloves (Syzygium aromaticum) 850 trees, soursop (Annona muricata) 800 trees, avocado (Persea americana) 1000 trees, durian (Durio sp) 1200 trees and coffee (Coffea sp) 900 trees.

Based on the survey results and socialization in group discussions, the target to be carried out to improve the preservation of the taxon wealth of Arjuna mount forest in the second period of 2019-2020 was the planting of 18,000 trees in the area of Curahtangkil springs-Dayurejo, Puthukbunder-Jatiarjo and Talangwatu-Leduk. Some tree species planted include: (1) endemic plant species, namely: bendo (Artocarpus elasticus) 1000 trees, kluwek (Pangium edule) 1000 trees, breadfruit (Artocarpus altilis) 1000 trees, candlenut (Aleurites mollucanus) 1000 trees, gondang (Pangium edule) 1000 trees, breadfruit (Artocarpus altilis) 1000 trees, candlenut (Aleurites mollucanus) 1000 trees, gondang (Ficus variegate) 1000 trees; (2) springs plant species, namely: petung bamboo (Dendrocalamus sp) 2000 trees, sugar palm (Arenga pinnata) 1000 trees, banyan (Ficus benyamina) 2000 trees, epek (Ficus elastica) 1000 trees; (3) fruit plant species, namely: avocado (Persea americana) 1500 trees, oranges (Citrus sp) 1000 trees, coffee (Coffea sp) 1000 trees, soursop (Annona muricata) 1500 trees, durian (Durio sp) 1000 trees and guava (Psidium guajava) 1000 trees. One biological component in the forest was a plant. If biodiversity refers to all living things in the forest, the diversity of trees was all types of trees that were in the forest. Natural forests tend to naturally have various types of plants. Biodiversity was used in the assessment of forest health indicators caused by three things: (1) sensitive to change; (2) ecological system indicators; and (3) spatial, temporal and trophic heterogeneity. In the assessment of forest health, parameters that could be used for biodiversity indicators were the index of diversity, the index of similarity, the index of diversity, and the index of species evenness [9].

\subsection{Plant density}

Some of the obstacles faced in the Arjuna mount forest plants density were the height of the initial plant of 1.5 meters, and the size of the width and distance between plants was 10 meters x 10 meters (200 trees/ha). The results of verification after 3 years of plant maintenance showed that tree stands were rare, plant canopy density was less than $40 \%$ of canopy closure. The size of plant canopy density was divided into 3 canopy density classes [3], namely: (1) meeting stands, if there are more than 70\% canopy closure; (2) enough stands, if there are $40-70 \%$ crown cover and (3) rare stands, if there was less than $40 \%$ canopy cover.

Some of the successes in improving the density of Arjuna mount forest plants were (1) replacing damaged and dead plants with new plants with the same tree height, for 3 years of maintenance; (2) doing maintenance includes cleaning plants from grass, weeding plants, making firebreaks during the dry season, preventing plant diseases, fertilizing and administering drugs, weeding from weeds, giving water during the dry season and protecting plants from natural and human damage. Conduct joint monitoring, directly at the planting location every 4 months, and make a report as a basis for corrective and preventive actions. Figure 6. shows the plants density in the spring area of Lajer, Dawuan and Watupereng.

Plant density was a value that shows the number of species of plants in each unit area. Plant density was related to competition between plants in getting sunlight and nutrients. Optimal plant density was closely related to plant growth in need of water, nutrients, and oxygen that was absorbed mainly by the roots and radiation and $\mathrm{CO}_{2}$ absorbed by the leaves under sufficient conditions. Lack of water, nutrients, and light radiation causes plant growth to be hampered so that plant density was not optimal. Based on the survey results and socialization in the group discussion, the targets to be carried out to improve the Arjuna 
mount forest plants density in the second period of 2019-2020 were (1) preparation of healthy plant seeds; (2) seedlings of various species (endemic plants, springs and fruits); (3) uniform plant height; (4) sufficient nutrient content for plants; (5) availability of water for plants during the dry season; (6) treatment of plants from pest and weed disorders; (7) fertilizer application; (8) sufficient sunlight for plants.

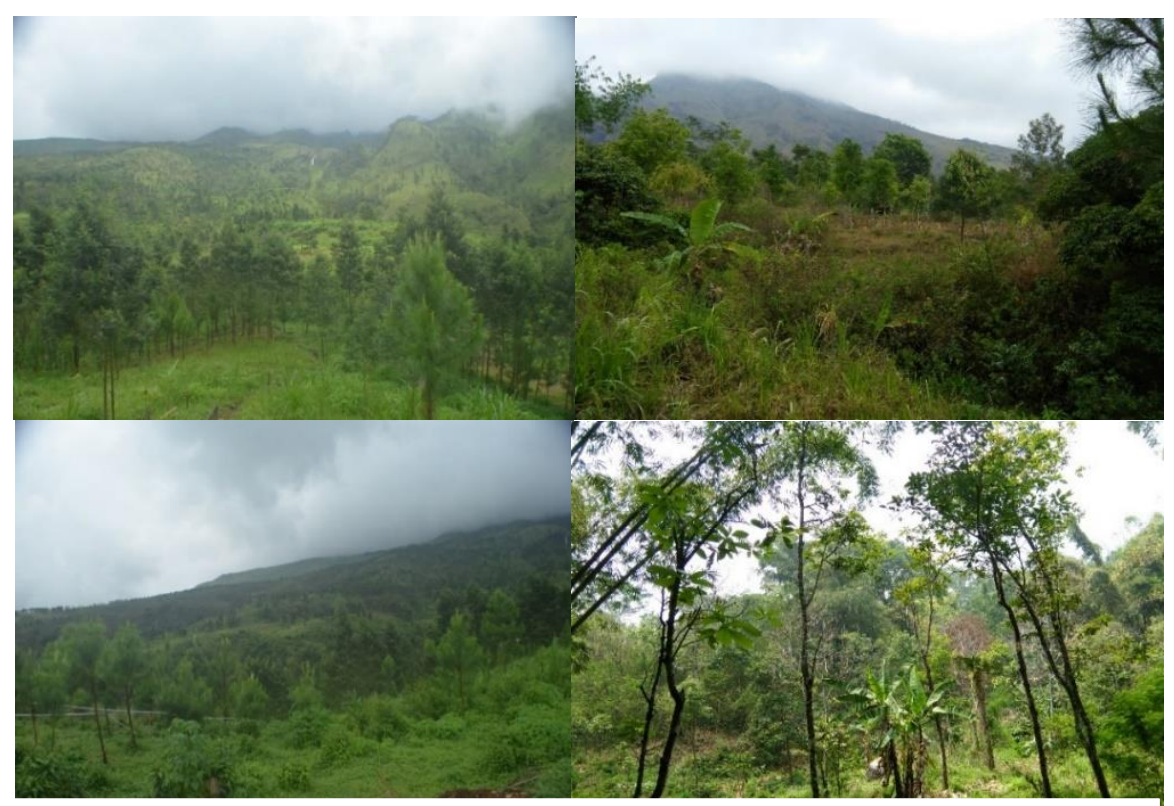

Figure 7. Plant density of Lajer, Dawuan, Sumberkuning dan Watupereng springs area

\subsection{Structural model testing}

The relationship of the influence of forest vegetation profile variables on the preservation of spring water sources was very significant (0.004) with a positive CR of 2.914 , Table 1 . Because the $p$ value obtained $>0.05$ and the $C R$ was positive and $>1.96$ it could be concluded that the forest vegetation profile has a positive and significant effect on the preservation of springs. The better the profile of forest vegetation, the preservation of springs will be better, and vice versa. Vegetation profile components such as canopy, litter /humus and root system, play an important role in maintaining the water system, namely in terms of: (1) evaporating water (transpiration); (2) absorbing water into the ground; (3) reducing the kinetic power of raindrops; (4) increase the capacity of the land; (5) to store water in the soil; (6) reducing runoff and (7) reducing soil erosion [10].

\section{Conclusion}

Plant vegetation profiles in Arjuna mount springs and forest conservation include vegetation stratification, bird wealth, taxonomic wealth and plant density

- The vegetation stratification profile had a significant effect on the springs and forest preservation on Arjuna mount, and the respondent's approval rate was $58.1 \%$

- Bird's wealth profile had a significant effect on the springs and forest preservation on Arjuna mount, and the respondent's approval rate was $60.5 \%$

- The taxonomic wealth profile has a significant effect on the springs and forest preservation on Arjuna mount, and the respondent's approval rate was $61 \%$

- Plant density profile has a significant effect on the springs and forest preservation on Arjuna mount, and the respondent approval rate of $58.6 \%$ 
The estimated value of regression weights for each indicator of plant vegetation profile for the preservation of forests and springs of Arjuna mount include the following: vegetation stratification $=1.00$, bird wealth $=1.05$, taxonomic wealth $=1.11$ and plant density $=0.98$. This condition shows that according to respondents the plant vegetation profile had a significant influence on the springs and forest preservation of Arjuna mount. The forest vegetation profile has a positive and significant effect on the preservation of springs. The better the profile of forest vegetation, the preservation of springs will be better, and vice versa.

\section{References}

[1] Gaston, K.J. and J.I. Spicer, 1998. Biodiversity: an introduction. Blackwell science. Oxford; Malden. Ma. USA

[2] Indrawan M, Primack RB, SupriatnaJ. 2007. Biology conservation. Obor foundantion Indonesia, Jakarta

[3] Indriyanto, 2006. Forest ecology. Jakarta: Bumi aksara publisher

[4] Jhon, MacKinnon, Child G. and J. Thorsell, 1993. Management of protected areas in the tropics. Gadjah Mada University Press. Yogyakarta

[5] Leksono, A.S., 2011. Biodiversity: theory and application. Universitas Brawijaya Press. UB Press

[6] Mardiastuti A, Salim LR, Mulyani YA. 2001. Sulawesi hornbill eating behavior on two types of Ficus in Lambusango wildlife reserve, Buton. Conservation media. 6 (1): 7-10.

[7] Oldeman, L.R. 1992. The Global Extent of Soil Degradation. In Greenland, D.J. and Szobolcs, I. (Ed). Soil Resilience and Sustainable Land Use. CAB International. 561 pp.

[8] PT. Sorini Agro Asia Corporindo, 2017. Forest rehabilitation program for Arjuna mount forest. Prigen Pasuruan

[8-9] Safei, R.S. and M.K. Tsani, 2016. Forest health. Forest health assessment using forest health monitoring techniques. Plantaxia. Yogyakarta

[9-10] Soerianegara I. and Indrawan. 1978. Indonesian forest ecology. Faculty IPB. Bogor. [10-11] Solimun, 2002. Structural Equation Modelling (SEM). Prints I. Publisher of state university of Malang. Malang, Indonesia

[11-12] Supranto, J. 2004. Research proposal by research. UI Press. Jakarta

[12-13] Wiyono, A. 2008. Preservation of R. Soerjo Forest Park to Maintain the Availability of Water and Biodiversity. Kaliandra foundation, Gamoh-Dayurejo Pasuruan. USAID 